\title{
Macrocytic Red Blood Cell
}

National Cancer Institute

\section{Source}

National Cancer Institute. Macrocytic Red Blood Cell. NCI Thesaurus. Code C13112.

An abnormally large red blood cell occurring mainly in anemias (as pernicious anemia), also called megalocyte. Lack of vitamin B12 and folic acid could also cause macrocytes. $(\mathrm{NCl})$ 